\title{
Bridging the Race Barrier: Between "Sakai" and "Malays" in the Census Categorisations of British Malaya
}

\begin{abstract}
Racial boundary-making has been an oft highlighted theme in the study of colonialism. The most overt symbol of British attempts to make sense of the peoples in the Malay Peninsula is the classification of people according to "race" in the censuses conducted during the colonial period. Drawing on studies of censuses which aim to denaturalise essentialised racial categories, I aim to complicate the depiction of British categorisation in order to show that races and the social identities on which they were based were not static by highlighting the gradations incorporated into the census between "Sakai", the indigenous peoples, and "Malays", the main native group in Malaya. Introduced in 1911, the category of "tame Sakai" was as a way of quantifying individuals who could not be categorised as either indigenous or Malay. In the process, however, the factors for inclusion in the original Malay and aboriginal categories themselves became subject to debate. Though in many instances, racial classification amounted to a rigidifying of identities, the case of "tame Sakai" highlights an instance of uncertain categorisation which was outwardly acknowledged within the census. The various discourses pulling at the Sakai category show races not as ideal existing types of humans, but a complex and sometimes contradictory manner of understanding people in Malaya.
\end{abstract}

Keywords: history of colonial Malaya, census, racial categorisation, indigenous people, government, tame and wild Sakai

Census data provide scholars with a wealth of information on the construction of categories, the reification and/or creation of racial ideas and the role of the state in the process of seeing and possibly controlling populations under its purview. The census has been most famously studied in relation to British colonialism in India by Bernard Cohn and others, particularly in the construction of caste (see Cohn 1987; Cohn 1996; Peabody, 2001). Recent studies on the census that focus particularly on the relationship between the census and racial discourse in a variety of locations such as the USA, Brazil, South Africa and countries in Central Asia have broadened the scope of census studies to include the colonial and post-colonial periods in a changing state's 
history and their multiple and specific effects on their respective locations (Noble, 2000; Kertzer and Arel, 2001, Khalfani and Zuberi, 2001; Ferrando, 2008). For the case of Malaysia, studies by Hirschman (1986; 1987) have introduced the idea that racial categories were not self-evident and did in fact change through time, while Nah (2008) analysed the impact of post-independence census classification on identity perceptions among indigenous people of Malaysia. A central thread running through most, if not all, studies on the census is an attempt to denaturalisation the categories of the census, and to show how categorisation is subject to change and thus not something objective or natural. This article is part of this larger group of scholarship that seeks to denaturalise and deconstruct racial categorisation in order to further an understanding of race in British Malaya as an idea more contingent on the perception of a person's place in society and in relation to others, rather than on readily discerned biological essences. I do this by showing that during the colonial period of Malaysia, when the territory on the Malay Peninsula was known as British Malaya, there was already trouble determining who was of aboriginal race or races and how to categorise people by race. ${ }^{1}$ Through an investigation of the conundrums faced by census takers and reporters, I illustrate how ideas of aboriginal races in the census did not always quite fit the people who were being categorised, resulting in disagreements about who was aborigine, Malay or in-between. Evidence of the varied manner in which aborigines and Malays were classified in the pages of the colonial censuses is a direct critique to the continued "racial passion” felt by many in present-day Malaysia who approach race as unchanging essences in

\footnotetext{
1 Throughout this article, I use the terms 'indigenous' and 'aboriginal' interchangeably. While it is more prevalent today to refer to the people in question as 'indigenous' peoples, I retain the term 'aboriginal' people since historical sources predominantly use this term as a neutral (non-derogatory) word to refer to groups of people known today as indigenous. I use both terms in the uncapitalised form for the sake of uniformity, and without meaning any disrespect to indigenous communities now or in the past.
} 
people from time immemorial and who base discriminatory practices on deterministic ideas of race (Lim, 2008).

This article also contributes to studies on how census bureaucracy, organisation and knowledge production were intrinsically part of larger state contexts, historical circumstances and present day political, social and economic situations and thus reflective of the power structures and struggles within these varying spheres. Contrary to the assertion of Talal Asad where he argues that ethnographic practice is more responsive to the situation on the ground than statistics (2002), ${ }^{2}$ my study adds to this discussion by pointing out ways in which the "Sakai census"3 (as the census of indigenous people in colonial Malaya was called) did not conform to the stereotypical characteristics of censuses according to Asad in two ways: firstly, the Sakai census was not a completely unilateral formulation of categories and incorporated unconventional methods of classification and local ideas of difference, and secondly, that the census privileged a changing present as well as that of an invented past (Kertzer and Arel, 2001). The way in which the census categories changed to address a changing present illustrates what U. Kalpagam has termed "the translation of experience into social knowledge" (1999, p. 148), and then from social knowledge to government and scientific knowledge in the censuses. Both distinguishing features of the Sakai census underline the earlier point about the constructedness of the census and racial

\footnotetext{
${ }^{2}$ To be fair, Asad used "statistics" to mean "social surveys and probability theory", while the statistical data I refer to in this article refers primarily to aggregated data divided into fields such as sex, location, occupation and age and the reports that accompanied the census tables (2002, pp. 66-67). However, the point remains valid when looking at the census as a whole that employs figures to justify a particular vision of the population.

${ }^{3}$ The term "Sakai" has a long and checkered history. From pre-colonial times onwards, the word has been used as a name for a group of people, as specifically referring to indigenous people and/or as a derogatory term with connotations of being wild and uncivilized (Nah, 2008). The term, however, appears frequently in colonial records. I maintain the use of the term to indicate the varying discourses (roughly speaking either anthropological or governmental) surrounding indigenous people and the ways in which the use of the term oscillates between these differing meanings. Henceforth, Sakai will appear with the capitalised first letter and without quotation marks. These, however, are implied.
} 
categories by uncovering even more ways race categories were pulled in one direction or another depending on time period and which bases of knowledge were used.

\section{The Problem of Race in Malaya's Censuses}

In Benedict Anderson's study of the incipient nationalisms in Southeast Asia and the colonial institutions that fed them, he writes that "The fiction of the census is that everyone is in it, and that everyone has one - and only one- extremely clear place” (1991, p. 166). Putting people in their place was indeed the aim, and the very heart of the problem, of the census of aborigines in Malaya. At the meta-level of Malaya's narrative in the census, there was the clearly demarcated group of Malays as natives, and three separate groups of indigenous people. At the same time, when reading the census chapters specific to Malays and indigenous people, this neat separation could not be clearly enacted without explanation because of the uncertainties in identification. This section of the article will delve into the problems of racial classification in Malaya, the discourses that were connected to the category before focusing on the particular problems with counting of aborigines specifically.

The census data that form the basis of my analysis on race categories in general and aborigines in particular derive from a variety of governmental and semi-governmental publications. Official census data ranges from 1871, when the first census of the Straits Settlements (Penang, Melaka and Singapore) was published, until 1931, when the last census of British Malaya was taken before the Second World War. The Straits Settlements were colonised earlier than other territories on the peninsula and, therefore, the earliest census data available is for these territories (McNair and Knight, 1871; Dunlop et.al, 1881; Merewether, 1891; Innes 1901). The remainder 
of the states on the Malay Peninsula came under British control at different times from the late nineteenth to the early twentieth centuries, and were grouped administratively according to the Federated Malay States (FMS: Perak, Selangor, Negeri Sembilan and Pahang) and the Unfederated Malay States (UMS: Kedah, Kelantan, Terengganu and Johor). I also refer to censuses that cut across all states and the Straits Settlements, as well as individual state counts that might not have been comprehensive across the particular state (Selangor Government Gazette, 1891; Perak Government Gazette, 1891; Hare, 1901; Pountney, 1911; Nathan, 1921; Vlieland, 1931).

One could approach attempts to count people according to race as part of the culture of British colonialism in the nineteenth and twentieth centuries (Dirks, 1992, pp. 6; Pels, 1997, p. 176). There are two aspects to the endeavour of counting by race that deserve some attention before dealing with the specific enumeration of indigenous peoples. The first aspect of note is that there were "human inventories" at all (to borrow a phrase from Norbert Peabody), and the second is that those inventories were taken according to racial categories. As Anderson and Appadurai have pointed out, censuses were part of the colonial imagining of the state under its purview both for those in the colonial bureaucracy locally and in the metropolis. The process of quantifying and categorising people through census operations, and the subsequent use of the census data, were ways through which colonial power could be exerted in colonised areas (Anderson, 1991, p. 163; Appadurai, 1993, p. 328) and was part of taming a particular area and reigning it into being knowable. That British colonial officers wanted to know the population by race was due to broader trends within knowledge acquisition about people where race was seen as one of the 
most important markers which, as will be made clear, subsumed other categories such as religion and way of life (Manickam, 2012, pp. 3-4).

Racial categories had, for colonial officials, unquestionable utility in knowing Malaya. Yet, counting by race was a problem, though one which was not always acknowledged. The problem stemmed partly from different understandings of the term 'race' when applied to various communities in Malaya. Though a more detailed look at how each community was categorised according to race is outside the scope of this article, some observations can be made to show the uneven conceptualisations and applications of ideas of race within the census. The terminology used and the kind of information that was to be collected differed for each group of people, illustrating the incommensurability of the meaning of race for each group. For instance, the 1901 report written by G.T. Hare commented that "the column 'Race' should be made clearer as far as the Chinese are concerned by making it more apparent that the race or tribe of Chinese is to be determined by tongue and not be birthplace” (p. 16). For the Chinese, all were Chinese yet difference in race was to be measured by language. The categorisation of Indians posed continuous challenges for census officials. Indians professing the Sikh religion were commonly categorised as Bengali by race, making the religious, racial and place name synonyms of one another. Other groups, such as Europeans, were given special attention in the censuses with minute racial subcategorisations even though they were a numerically small group within the entire population (Hirschman, 1987, pp. 563-565, 574-575). Several words were used as group terms for people such as nationality, though through the years the preference for the word race became obvious among census superintendents. Again in 1901, Hare explained that “[w]herever the word 'Nationality' is employed in the Census Forms or in the Census Report Forms, it is 
intended to mean the same thing as is comprised in the wider and better expression 'Race' - e.g. there cannot well be, for instance, a Eurasian nationality”. He suggested that for the next census, all sections that used "Nationality" should switch to "Race” (xciv, p. 13).

It is already obvious that race encompassed more than just differences in bodies. It encompassed language, religion, lifestyle and political status. The weight attached to each of those elements depended on the government and census bureaucracy of the day and the input of informants and respondents. In the 1921 Census report written by J.E. Nathan, he introduced the chapter on "Race” by stating:

For tabulation purposes the total population was split into six main racial divisions, Europeans, Eurasians, Malays, Chinese, Indians and "Others." Not one of these is one race.... In all, no less than 28 different races were enumerated in British Malaya in numbers exceeding 1,000, and the present chapter deals with the separate races constituting the main racial divisions (p. 70).

Nathan acknowledged that each racial division was not really “one race”, but rather that they were aggregated together from a longer list before the census report settled on the essential few. As has been elegantly illustrated by Hirschman in a table comparing the changes and contractions in race categories throughout Malaysia’s colonial and post-colonial periods, the choice of which races to include was a political decision that changed from one year to the next in line with government ideologies and uses(1987, pp. 571-576). That the census information gathered was to serve government needs was explicitly stated in 1931 by the census' director, C.A. Vlieland:

the word "Race" is used, for lack of a more appropriate term, to cover a complex set of ideas of which race, in the strict or scientific sense, is only one small element. It would be of little use to the administrator or the merchant to attempt a 
classification of the population by race in the ethnographic sense, to say nothing of the fact that any such tentative classification would be highly controversial.... In default of anything resembling a definition of the term "Race" as used in this report, perhaps the best way of conveying its meaning in a few words is to say that, in asking the question of an individual "What is your race?" the census authority is trying to obtain an answer of the same nature as we expect when we ask in ordinary non-technical conversation "What is that man?" (pp. 73-74)

Besides the influence of government outlooks in determining racial categories, his quote further indicated that the meanings of race employed by several segments of the population made their way into the census. For instance, being Muslim was a prime marker for membership in the Malay race according to many locals and officials alike. Vlieland intimated that social categories and social differentiations were most important. The question "What is that man?” could be answered in a number of ways, depending on how the individual was placed within society, who was doing the identification and being identified, and which aspects of their being were seen as most important. The foregrounding of this aspect of identification shows that there was a certain receptiveness to ideas from non-governmental spheres when producing the census. While knowledge of past affiliations of people undoubtedly played a role in their classification, the present identification of the person was valid as well or even more so, as we shall also see with the inclusion of the tame Sakai category. All of these aspects reflect the highly subjective basis for racial identification even while the presentation of data in numbers and tables gave the impression of clarity and ease in identification.

When it came to enumerating indigenous people or aborigines, the enumerators appeared more at sea than when dealing with other populations because of the difficulty in locating them as compared to most of the population of Malaya who were counted in dwellings. Unique bureaucratic procedures were put in place to deal with aborigines, adding complexity in the 
levels of reportage from the collection of data to the final publishing of the report. Special enumerators were commissioned to enter the jungle to locate and count members, or to call feasts with headmen who would invite indigenous peoples to attend and subsequently be counted. The circular ordering the commencement of the 1901 census of the FMS noted specifically that "it is highly desirable that special efforts be made to ascertain the number of Sakai and other indigenous peoples living in each state. If necessary, a few trifling presents might be offered to them in various districts, so that they may be induced to come to the nearest villages for the purpose of the census” (Hare, 1901, lxxxvi-lxxxvii). This practice continued in 1911 when census superintendent Pountney commented that the cost of the census was very low considering that "special enumerators” had to be “despatched to visit the Sakai encampments” (1911, p. 91).This method of sending people to the abodes of aborigines or organising feasts became known as the Sakai census as opposed to the general census where enumerators went door-todoor and counted occupants of households.

Special chapters were also devoted to aborigines in the census reports of the 1900s, showing that the subject of aborigines required expert knowledge from the rest of the population and was distinctive. For the 1911, 1921 and 1931 censuses, one chapter was dedicated to aborigines with external experts called in to contribute on census methods, to look at the census data and/or to write the report. The chapter on "The Sakai” in the 1911 census, the first such chapter devoted specifically to the topic of aborigines, was written by R.J. Wilkinson, a colonial scholar-official who also studied topics such as indigenous peoples and the Malay language (1911, p. 68; Wilkinson, 1971). The year before, Wilkinson had published a pamphlet on “The Aboriginal Tribes” which was part of a series of papers published partly as government instruction manuals 
to help British cadets pass the entrance exam to the Malayan Civil Service (Wilkinson, 1910;

Burns, 1971). In 1921, notable scholar of Malay Richard Winstedt was the author of the chapter on aborigines (“The Aboriginal Races”), and in 1931, the superintendant of that year wrote the report himself though he did not have any specialised knowledge of Malaya or aborigines. ${ }^{4}$

Due to the various people involved in the counting of and reporting on aborigines, information on aborigines in the census was at once governmental, anthropological, linguistic and statistical at different doses depending on the census year. The reports included details on the difficulties in locating and identifying aborigines, the methods used, and the idiosyncrasies of the entire endeavour of counting. In many instances, there were inconsistencies in definition from one census to the next and problems of enumeration that called into doubt the reliability of the count. But the unreliability of the count, such as the ways in which the count was changed, repackaged and rethought, is precisely the important aspect of the Sakai census that reflects the difficulty in categorising aborigines and, what is more, even merely identifying who was aboriginal as opposed to Malay at certain points in time. Evoking the connections between colonial imagination, knowledge production and government bureaucracy, Anderson commented that the census “tried carefully to count the objects of its feverish imagining” (1991, p. 169). The term imagining here in reference to counting aborigines in Malaya does not deny the existence of people who lived in the forest and practiced a particular lifeway. Rather, it highlights the process by which forest and hill peoples were brought into a body of anthropological and governmental knowledge by anthropologists and the colonial state, a process which entailed classifying them,

\footnotetext{
${ }^{4}$ This can be explained by the fact that the superintendant of the 1931 census, Vlieland, was not particularly interested in the subject of aborigines and felt that much of the information presented on the subject in previous years was superfluous. It is noticeable that the specific chapter on "The Aboriginal Races" for that year had much less information on these groups, whereas previous reports included additional details for the interested reader.
} 
connecting them to other 'savage' peoples elsewhere in the world, and discerning differences between them and another group equally difficult to demarcate called Malays. Problems in identification cropped up because the assumptions held by census takers about aborigines and Malays did not fit the people who were being categorised. Due to the distinctiveness of the Sakai census, however, certain strategies were employed to capture those who were considered inbetween categories, though these too occasionally offered up their own issues.

\section{Aborigines and not Malays, Malays and not Aborigines}

One of the main assumptions and guiding principles governing the taking of the census was the separation between Malays and aborigines. Several scholars of indigenous peoples in Malaysia have examined this ideological and governmental separation, focussing primarily on the situations after the independence of Malaysia from the British in 1957 (see Nah, 2003; Dentan, 1975; Rusaslina, 2011; Gomes, 2009). However, the way in which this intellectual separation operated in the historical period of British rule in Malaya, and specifically though the apparatus of the census, has not be fully investigated. In the 1921 census report written by Nathan, the general description of the inhabitants of British Malaya started with the heading "The Aborigines":

The earliest inhabitants of the Peninsula were probably the Semang, a race of Negritoes, related to the Aetas of the Philippines.... Superior to them in culture are the Sakai, a race supposed, mainly on linguistic grounds, to have migrated to the Malay Peninsula from Indo China.... In Negri Sembilan and Johore are found a number of aborigines, usually called Jakun or Biduanda; it is now generally held that their real language is Malay, though not quite the Malay of the civilised Malay of the Peninsula (p. 1).

The intellectual separation between Malays and aborigines built on another more fundamental assumption of the bounded and knowable categories of Malays and aborigines respectively. As 
Joel Kahn highlights, the Malay category itself was subject to constant ideological work by colonial officials so as to project homogeneity in the group's background (based primarily on the Malay Peninsula) and way of life (subsistence agriculturalists in the kampung). Kahn disputes this representation of Malays and paints a convincing picture of multiplicity in the components of the Malay category by focusing on people who came from other parts of the archipelago but were nonetheless included in the overall Malay category (2006, pp. 60-62). Despite the different peoples who comprised Malays, the colonial idea of Malays as farmers originating in kampungs on the Malay Peninsula was actively endorsed in the census and used as the basis for comparison between Malays and aborigines.

For aborigines, on the other hand, anthropological ideas of race and migration proved most salient in explaining the apparently fundamental difference with Malays. The division of aborigines into three racial types reflected the standardisation of aboriginal divisions by anthropological methods first proposed by W. W. Skeat (Manickam, 2012, p. 15). Skeat was a prominent figure in the application of physical anthropology to the study of indigenous peoples in Malaya. He led the Cambridge Expedition to the Malay States from 1899 to 1900 that established three racial divisions of aboriginal peoples in Malaya: the "woolly-haired Negrito tribes called Semang”, “the wavy-haired tribes called Sakai” and "the straight-haired tribes called Jakun”. 5 This racial categorisation also amounted to a ranking, with Semang considered by Skeat to be “a representative of one of the wildest races of mankind now extant”, while Jakun were placed closer to the civilised Malays by their informal designation of "savage Malays"

\footnotetext{
${ }^{5}$ Skeat built on the work of other scholars of aborigines, in particular that of Rudolf Martin whose book on Malaya's aborigines was published in 1905, just one year prior to the release of Skeat's own book (Martin, 1905; Skeat, 1906). Though there were differences between anthropologists' classifications of aborigines at the time (see, for instance, Martin, 1905 and Annandale, 1903), the three-race classification has thus far endured the test of time.
} 
(Skeat, 1902, pp. 124-127). This migration-based theory of the peopling of the Malay peninsula is generally still held by scholars and lay-people in Malaysia today and is known as the kuih lapis or layer-cake theory. However, scholars such as Benjamin and Nah reject this hypothesis of wave migration and suggest instead that other theories, such as in situ differentiation, could equally explain the different lifeways and physical features of people on the Malay Peninsula (Benjamin, 2002; Nah 2008). Most recently, Scott has also criticised wave migration theory as a basis for understanding tribal groups (who in the case of Malaya are often also glossed as indigenous people) by arguing that "the invention of the tribe is best understood as a political project.” Scott then uses this “radical constructionism” approach to argue that tribes, in its evocation of people that are cut off from outsiders and are distinct from an 'other', never existed (2010, pp. 256-259). Approaching indigenous people from this angle allows us to ask what political projects and which parties were involved in delimiting the group(s). For the case of Malaya, the political projects that facilitated the emergence of indigenous people as different from Malays (and Malays as different from indigenous people) were anthropological applications of race in Malaya which, in tandem with (or possibly more subservient to) the governmental imperatives of having a stable Malay population, constructed racial boundaries through the census. ${ }^{6}$

The implications of the layer-cake theory, however, meant that at one level the census takers and reporters assumed a biological and cultural separation between people known as “Malays” and “aborigines” respectively and this thinking was supported by the cutting edge anthropological

\footnotetext{
${ }^{6}$ It should also be said that both anthropological and government ideas on the separation between Malays and aborigines were themselves based on the understanding of difference expressed by Malay and aboriginal informants (see Manickam, 2011). However, the details of the categories were far more intricate than that which was initially recorded from informants.
} 
research of the day. Again in 1921, Nathan explained that the origin of "the Malay race” was almost wholly unconnected to that of aborigines (p. 1). Vlieland in 1931 argued that aborigines were “ethnographically far removed from the Malays but more truly 'people of the country' than any other race” (p. 38). ${ }^{7}$ Despite this separation, observers in Malaya had long noted the trend of some people identified as aborigines who displayed the lifeway, language and look of stereotypical notions of Malays (Manickam, 2012, pp. 9-10). These aborigines were commonly known by the phrase “tame” Sakai or "tame” aborigines, phrases which appear in informal colonial sources and some scholarly works on Malaya (Crawfurd, 1856; Miklouho-Maclay, 1878; Maxwell, 1879). The remainder of this article will discuss the possible provenance of this phrase, the ways in which the term suggested movement between races that was counter to the assumption of static racial essences, and the term's codification in the census.

The separation of aborigines into tame and wild is mirrored in other colonial and present day situations. Teng (1999) and Barclay (2005) have explored a parallel conception in colonial Taiwan where Han Chinese used the terms “raw” and "cooked” Barbarians in order to distinguish between indigenous people who were outside the purview of Qing control and those accustomed to Qing culture. Fiskesjo has also investigated this phenomenon in imperial China where "raw" and “cooked” were used to distinguish people outside and just inside the periphery respectively (1999; 2002). The salience of the discourse of "tame” and "wild” in Malaysia is apparent in Lye's recent article that explores these ideas in the management of and conceptions

\footnotetext{
${ }^{7}$ By virtue of undoubtedly being from the region, however, aborigines were nonetheless grouped under the larger heading of "natives" or "allied races” of the Archipelago with Malays. Occasionally, aborigines were counted as part of the "Malay” population since Nathan noted that "under the heading 'Malays' are grouped all the native peoples of the Malayan Archipelago” (1921, p. 72). In 1931 the Malay race category underwent change and aborigines were now included under the heading "Malaysian” but not "Malay" (p. 75).
} 
about Taman Negara, a large protected area and forest reserve on the Malaysian peninsula (2011).

The tame and wild concepts as applied to aborigines in Malaya have their particular origins in the Malay terms jinak and liar (Dentan, 1997, pp. 109-111). Peabody, in discussing the case of late precolonial and early colonial India, suggests that “colonial discourses often built upon indigenous ones in ways that inflected local politics about which the British initially were only dimly aware” (p. 819). Similarly, scholars of Malaya in the late-nineteenth century borrowed phrases used by their Malay-speaking informants concerning Orang Sakai liar and Orang Sakai jinak (the wild and tame Orang Sakai) (Miklouho-Maclay, 1875; Maxwell, 1879). In these writings, the Malay terms were freely translated into the English for tame and wild, since there already existed parallels between the connotations surrounding the terms in both Malay and English. The entries in dictionaries of the Malay language give us further hints of the meanings of jinak and liar. Since the nineteenth century, jinak connoted tameness, the state of being domesticated, and meek. The additional definitions ‘docile, tractable’ and 'easy or reconciled to one's position' show that acceptance of a hierarchical system, a larger society or state perhaps, was part and parcel of tameness (Marsden, 1812; Crawfurd 1852). To lie outside of that scheme was thus to be wild. ${ }^{8}$

Tellingly, Crawfurd’s 1852 dictionary translated jinak as ‘Tame, not wild’, defining tameness in opposition to wildness but also suggesting more than an opposition which was the intrinsic

\footnotetext{
${ }^{8}$ Sakai also appeared in dictionaries as a entry on its own. In the early nineteenth century, the term was often translated as slave, servant, follower or dependent, but later in the century it began to take on the meaning of aborigines (Manickam, 2011, pp. 102-103).
} 
connection and mutual dependance of the two terms. Tameness in the Malay peninsula was understood by scholars, colonial officials, and the informants who guided them as having the characteristics of being Malay and no longer wholly aboriginal, while wildness that of nonMalay forest- or sea-dwelling people. Therefore, tameness could connote a range of states from having once been wild but now no longer (to the extent of being identified as Malay) to not quite aboriginal. It is this last characteristic of tameness, that of movement from one category (wildness) to another (no longer wild, or tame), which defies rigid racial classification which assumed that membership in one race meant a different biological and cultural history. Thus, tameness and its implications of movement between these stereotypes further confounded the rigid separation mentioned before between Malays who were the most developed of the Malay Peninsula's natives and the less-civilised aborigines who were supposed to have arrived earlier.

The term tame or settled Sakai was gradually introduced in the census precisely in order to capture people who were in-between categories and possibly moving towards becoming Malay. In general, the names given to aborigines and Malays in the census prior to the introduction of the tame Sakai category in 1911 did not suggest movement between races. Rather, census categorisation reflected the changing understandings of aborigines' links to other groups. For instance, aborigines were enumerated since 1871 where a group of "Mantra" were counted in the Straits Settlements (McNair and Knight, 1871, pp. 6, 32). "Mantra” was then taken away and the population once included under that term were now called generally "Aborigines of the Peninsula” (Dunlop, et. al. 1881, p. 3). Similarly for Malays, the groups that comprised that category may have shifted but not due to changes from one race to another. Instead, what changed were the assumptions about the connections between groups. Malays in Kedah, for 
example, were once counted as foreign because they were under Siamese and not British control. Once Kedah became a British protectorate, they were reclassified as local Malays (Hirschman, 1987, p. 30). In both these instances, what changed throughout the years were the associations surrounding aboriginal groups and Malays in Kedah.

The changes in the enumeration of aborigines that occurred in the 1901 and 1911 censuses, however, signalled an acknowledgement of the movement between races that were still seen as separate. One of the main indications of such a movement was the appearance of aborigines who were not counted in the forested areas of the peninsula or as nomads. As mentioned previously, the knowledge of aborigines who lived in remote places that were difficult to reach by enumerators brought about the group method of enumeration in 1901 where headmen and influential members of society who had contacts with aborigines were asked to invite them to a feast. This effectively created a special census of aborigines separate from the main count. But along with the intended effect of a more comprehensive count of Malaya’s population was the unintended effect of highlighting people who were identified by themselves or others as aborigines but who lived in the general population. In the summary table of the distribution of the main races, “aborigines” came to a total of 18,574 people, out of which 1,397 "Sakai” were enumerated in the general population (Hare, 1901, p. 30). This indicated that they were not living in remote places at the time of enumeration, that they had occupations like other 'ordinary' inhabitants, and that were living among people in one of the other major racial headings. Besides noting the number of aborigines counted outside the Sakai census, they were otherwise not separated from the general Sakai category and no other information was provided on this group. 
This was not the case in 1911 where tame Sakai appeared in the report after further thinking into aboriginal classification by officials. In this year, only 941 people were counted as aborigines in the general population. Even though this was less than those counted in 1901, they were now given a separate section in the tables on aborigines and a separate name: tame Sakai. Wilkinson, who wrote the chapter on aborigines for that year, stated that “including 'tame' Sakai the complete total [number of aborigines] is 27,218” (1911, p. 68). This in-between category came about because stereotypical elements of Malays and Sakai/aborigines were not fulfilled on all counts. In this instance, the place of enumeration was the determining characteristic of tameness. In fact, the place of enumeration was already a factor in the differentiation of aborigines in 1901 even though no term was employed then to describe this segment.

Approaching the occurrence of tame Sakai from this aspect, the term could be considered merely as a filler, a term used to capture aborigines who were still aborigines even though they were counted in the regular census. However, additional notes about tame Sakai show it to capture the dilution of aboriginality and the process of becoming something else, namely Malay. A few crucial aspects indicated a movement into Malayness such as inter-marriage and lifestyle attributes such as dress and living circumstances. Wilkinson explained that tame Sakai were “people of aboriginal descent [who] were included in the regular census schedules through their marrying or settling down among the civilised peoples of the country” (1911, pp. 69, 72-74). Though he was not specific about which “civilised peoples” aborigines married or lived with, in another writing of his, it was clear that he specifically had Malays in mind. In Wilkinson’s 1920 publication in the series Papers on Malay Subjects about peninsular Malays, he explained that Malays had intermarried with aborigines but had "failed to absorb [them] completely” (p. 1). 
Marriage to Malays meant aborigines were on their way to becoming absorbed into a more civilised race, but not quite yet if they could still be identified (or identified themselves) as aborigines. In this case, the inbetween-ness in categorisation was brought about by the actual cohabitation of people known to be Malay and aboriginal respectively.

But inter-marriage in itself was not necessarily a prerequisite for tameness. Practicing a lifeway that was not stereotypically aboriginal (which was frequently thought of as a nomadic existence living solely in the forest or at sea) was also sufficient to spark ideas of tameness in the minds of enumerators and report writers. In his 1910 pamphlet on aborigines, Wilkinson further commented on the difference between "tame" and "wild” Sakai:

It may, however, be surmised that the "tame" aborigines differ from the "wild" only in the fact that they have discarded their old communal houses and the use of the bow and are losing other racial traits such as the making of bark-cloth and the painting and tattooing of the face. Briefly, they are becoming sophisticated (p. 18).

There was a further indication of the ideological overlap between lifestyle and tameness in the 1921 census report on aborigines. The writer of the 1921 chapter on "The Aboriginal Races”, Winstedt, changed the earlier 1911 "tame Sakai” category to "settled aborigines" and the general aboriginal population (who were not tame/settled) to "nomads" (p. 125). This change was maintained in the next census as well (1931, pp. 101-104). Winstedt wrote that, "it has been apparent to everyone who has come into contact with the wild tribes during the last few years that in many districts they are tending to settle down among Malays, and that, even where they are kept apart, they tend to lose their nomadic habits and form semi-permanent settlements" (1921, p. 125). The change in terminology can be attributed to prevailing notions about untouched aborigines being originally nomadic while aborigines who maintained some sort of 
permanent settlements were assumed to have adapted to this apparently civilised lifestyle through interaction with Malays. Different lifeways were placed on a gradation from wild to civilised, and were seen to be the essential state of certain populations and not others. Winstedt assumed that the change in lifeway and location (settling down among Malays, no longer practising a nomadic lifestyle) was indicative of tameness and he also noted the "merging of the aborigines into the Muhammadan Malay” (1921, p. 124). In line with Winstedt's understanding of the differences within the aboriginal population, the census data for 1911 and 1901 were reproduced in the 1921 report with the division between settled and nomadic aborigines in mind (1921, pp. 126-127).

The final section of the article discusses the irregularities in the codification of the racial terms in the census due to the various stages through which the census data had to travel before appearing in the report. Focussing on this aspect of the census process is yet another striking indictment of how the actual process through which people were identified racially was at odds with the idea of race as being an essential and obvious aspect of being. Perhaps not surprisingly, there are again similarities between the census process in British India as outlined by Cohn and the process of counting aborigines in British Malaya. Cohn mentioned that there were varying levels of interpretation at different administrative points when it came to recording and reporting caste. The journey taken before arriving on the printed page started questions asked and answered, then the recording and reporting of the answer to authorities higher up. The answer on caste would then be placed or reworked in view of how the information fit into larger conceptions of caste, and could be inconsistent from one place or person to another (1987, p. 243). Similarly, the actual categorisation of aborigines was complicated by the distance between the rationale behind 
census questions, the organisation of the census on the ground by district officers but who themselves relegated the task of enumeration to certain locals (most commonly mentioned as Malays), and eventually the collection and interpretation of data that resulted in a report in the census. Within this scheme, there was plenty of room for differing interpretations and standards for judging racial affiliation, as well as opportunity for external experts to impose an overarching racial scheme on the schizophrenic data.

One set of irregularities was the categorisation of aborigines at the level of the report which could differ substantially from the data collected by enumerators. For the 1911 census, Wilkinson had engineered the census questions where he compiled a list of words in Jawi (Malay in Arabic script) to be given to enumerators. These enumerators were to ask aborigines for the equivalent words in their language. Based on the list of words compiled, Wilkinson then divided the aboriginal population according to seven racial divisions: Negritoes, Northern Sakai, Central Sakai, Besisi, Jakun, Benum Aborigines, and Malay-speaking aborigines. This division was carried out despite his initial caveat that the tribes were difficult to locate and classify, and that they differed from one another in custom, and belief, and were very often of "mixed race". Divisions were further supplemented with bodily descriptions such as facial features, skin colour, and hair type (1911, pp. 69-70). ${ }^{9}$ Yet, when reading the specific reports by enumerators, it was clear that these divisions were imposed on the data afterwards and that supervisors and enumerators merely counted people as Sakai. For instance, Wilkinson separated the people enumerated in the district of Kuala Kangsar, Perak into three aboriginal races based on language

\footnotetext{
${ }^{9}$ It is not known how Wilkinson identified the bodily features of the individuals enumerated, since he did not carry out the collection of the word lists himself. It is likely that the description, like many others of aborigines, were based on prior knowledge production in general and not only or primarily on the individuals counted.
} 
(Negritoes, Northern Sakai and Central Sakai) whereas the extract of the enumerator's report on Kuala Kangsar mentioned that the census was conducted with "the services of a Malay who talked some Sakai” and it was not specified which aboriginal languages he spoke. Extracts from other districts confirm that the term Sakai was used throughout to refer to all aborigines and not the specific divisions of Wilkinson (pp. 70-72, 172).

Another instance of differences between enumerators and report writers was in the revision of terminology to refer to aborigines in 1921 to settled and nomadic from the original labels of tame and wild. This revision was again a top-down change that was not necessarily communicated to census enumerators as was evidenced by officers in charge of taking the census continuing to use the terms tame and wild to describe differences in the aboriginal community. For the district of Ulu Selangor, the District Officer wrote that “I have seen a good many of the 'tame,' there are no ‘wild’ Sakai left” (p. 131). The 1931 census continued the preference for the terms "settled” and “nomad", yet, as in the 1921 census report, additional information given by officers who took the census still used tame/wild distinctions (pp. 101-104). As with the example of the seven racial distinctions, the change in terminology seemed to be a later addition, a constructed framework laid over the information provided by enumerators and, in any event, not always adopted by enumerators.

It was also frequently the case that enumerators considered people "Malay" or "Other" whom report writers might have considered aborigines. In 1921, Winstedt noted in hindsight that aborigines were poorly enumerated in the UFM in 1911. He said that "In 7 out of 9 districts of Trengganu the Malay officers in charge reported that no aborigines could be found, an almost 
incredible statement in view of their large number in Ulu Kelantan” (1921, p. 124). The speculation about aborigines who were enumerated as Malay extended to the 1921 and 1931 censuses. In 1921, the situation in Negeri Sembilan was particularly fraught with such issues. Winstedt said that the decrease in the enumeration of aborigines there was most likely due to their being counted as Malays if they were Muslim, and not necessarily due to an actual decrease (pp. 124-125). In 1931, Vlieland noted the same situation:

It is ... certain that the conversion of the aborigines from their characteristic nomadic habit of life has been far more considerable than these [settled and nomad] figures suggest, and they have, of recent years, become progressively more assimilated with the Malays. Where no assimilation, or intermarriage has taken place, the aborigines still tend to lose their nomadic habits and form permanent or semi-permanent settlements marked by coconut and other plantations. It is fairly certain that many of these settled aborigines would not be detected as such by, and often would not admit their true descent to, any enumerator not well acquainted with them. Further, any aborigine who had been converted to Islam would be returned as "Malay" (p. 101).

While numbers and counting were "part of the enterprise of translating the colonial experience into terms graspable in the metropolis” and locally too, there seemed to be a continual distrust of the census even as the figures for tame and wild (or settled and nomadic) were presented (Appadurai, 1993, p. 326). It boiled down to who did the questioning, who answered, and which yardstick was used when determining categories that did not have definite boundaries themselves. Both Winstedt and Vlieland noted the key roles played by enumerators in the process of identifying aborigines, and frequently argued that the census of aborigines was only as good as the enumerators tasked with the "correct” identification of people’s race.

The next case highlights a situation where even an established professional assessment of racial divisions according to (one) anthropological yardstick came with its share of problems and 
disagreements among experts. Wilkinson chose his own method of basing divisions on language, but he was aware that this method was not one adopted by others in anthropology (see Wilkinson, 1910, p. 8). What was more, Wilkinson's method was criticised by the next writer of the report, Winstedt. In 1921, though Winstedt followed the method used by Wilkinson to determine race by using language as an indicator, he made a point of noting that this was “unscientific” and “offend[ed] the canons of the anthropologist” (1921, pp. 124-126). But since the data on aborigines for this year was not presented according to the seven racial divisions, and indeed this information was deemed superfluous by Winstedt, it is uncertain if the classification Winstedt arrived at was similar to Wilkinson's. In any event, Wilkinson's use of these divisions in the census closed off the discussion and made the divisions seem natural, as though they sprang fully formed from the lives of aborigines themselves. Winstedt opened the door slightly to discuss the validity of that division, but deemed it a more academic discussion that had no place in the census.

Lastly, there were even irregularities in the application of the in-between category of tame Sakai. The constant questioning surrounding the census data and methods of classification from the ranks of report writers themselves illustrates the fundamental problematic of the whole endeavour which was the difficulty of counting people as aboriginal, Malay or in-between when such identification was always a personal and an idiosyncratic decision. The extracts of the reports by assistant superintendents of the census show differing understandings of aborigines from Wilkinson's, particularly in relation to who was tame and wild. Determining language use and religious observation were particularly important to the judgment of tameness. However, depending on one's point of view, these factors signalled very different states of being. In general, there were at least two prevailing notions about the meaning of speaking Malay for 
aborigines: they were either still aborigines (Wilkinson’s “Malay-speaking Aborigines”) or they could be tame Sakai on their way to becoming Malay. Wilkinson was keen to stress this subtle difference when he wrote that Malay-speaking aborigines had not always “abandoned” their original language in favour of Malay. In fact, their language was Malay or a variant of it (1911, p. 72). The inclusion of this point by Wilkinson, however, suggests that others were not as discerning as he was when it came to the meaning of speaking Malay for determining racial affiliation. Here again, the question of the role of the individual interaction between enumerator and enumerated enters: if the enumerator asked further questions and the person was willing to divulge information about his/her lifestyle and background, a different classification might have resulted. Furthermore, contrary to Wilkinson’s thinking, it appeared that some enumerators considered any aborigine who showed up to a feast to be tame, while those who did not and who required more pursuing were automatically wild (1911, p. 172). There was no recourse to checking each and every enumerator's methods, and while some details of these idiosyncrasies were included in the report, the implications of the different interpretations for the resulting categorisation were not discussed.

From the privileged vantage point of the present, many of the observations on the census of aborigines have far-reaching implications, not only for the indigenous community, but any one subject to racial enumeration and thus to government policies linked to race. Similar judgements were exercised on many people in Malaysia’s past and present in order to produce a count of races (see Kahn 2006, Chapter 2) and a ideologically-laden report of the social situation. As mentioned by Appadurai in relation to British census activities in colonial India, the meaning and import of numbers were “often either nonexistent or self-fulfilling, rather than principally 
referential with regard to a complex reality external to the activities of the colonial state” (1993, p. 317). Such a complex reality was one that was not adequately captured by racial thinking in terms of separate waves of people and essences. Though there are no sources that detail the specific involvement of locals, and the responses of people classified as Sakai, Malay or inbetween to these classifications, the Sakai census and report were unique in that the documents do show certain local traces in the terminology and its application, and not just an imposition of foreign discourses. ${ }^{10}$ This oblique participation in the conceptualisation of the count, though not concrete nor always highlighted in the reports themselves, is nevertheless present and important to note in any historical reconstruction of ideas on aborigines.

\section{Concluding remarks}

In 2008, David Lim wrote that Malaysians today hold a passion for race that is difficult to break hold of. The colonial census reporters could similarly be said to have been in the throes of racial passion. They were influenced by a scholarly tradition that supported the assumption of separate races, and by a government that held deeply rooted ideas about the ideal roles and lifeways of segments of Malaya's population, all of which fuelled the desire to count races. But there were several facets to their belief in race, some aspect of which were incongruous with others. The notion of change from one race to another was one such facet that seemed to go against the overarching principle of separate races. Yet this aspect was included in the reports on aborigines since it became a more regular feature in the enumeration procedures to come across such individuals. In this instance, the census underlined the importance of tracking a changing present,

\footnotetext{
${ }^{10}$ The lack of local voices on this matter is unfortunately not unusual given that available historical documents pertaining to the census are heavily biased towards printed British colonial records and other government-linked publications in English.
} 
even though that present did not always agree with pre-formed underlying assumptions. Despite the principal of separate races of aborigines and Malays expressed at the meta-levels of the census, this principle was not always in operation in the Sakai census and reports.

The definiteness of separate bodies, histories and migrations into the peninsula (according to the layer-cake theory) was undone by the complexity of ideas used to gain a more comprehensive categorisation of aborigines. Categorising some indigenous people in the general population as tame brought up more questions and uncertainties, ranging from which characteristics indicated tameness to the application of tameness at different levels of the census operation. Going back to the main categories of Sakai/aborigines and Malay, issues in the tame category conversely brought to light variation in opinion on who was aboriginal or Malay with speculations by report writers on the under- or over-reporting of aborigines. While tame Sakai undid the narrative of separate races, the questioning of tame attributes compromised the naturalness of racial identities as a whole and the objectivity of censuses that count by race.

Highlighting these aspects of racial identification and census operations are important when questioning the objectivity of racial categories in colonial and present times. That people were counted, their numbers noted and presented in tables, often holds the sacred power of demanding to be taken at face value for what it purports to show about the population. Questioning how the categories and numbers came to be hopefully offers a powerful antidote to the aura of essentialised race categories and the policies past and present that are based on such data. 


\section{Census Material (by year)}

McNair, J. F. A. and A. Knight (1872) Straits Settlements. Census. Reports and Returns. 1871 (Singapore: Straits Settlements Government Press).

Dunlop, S., W. A. Pickering, V. Cousins, H. Hewetson, A. Knight and A. P. Talbot (1882) Straits Settlements. Population (according to the census taken in 1881) (Singapore: Straits Settlements Government Press).

Selangor Government Gazette (1891) CO 467/1.

Perak Government Gazette (1891) CO 467/2.

Merewether, E. M. (1892) Report on the Census of the Straits Settlements taken on the $5^{\text {th }}$ April 1891 (Singapore: Government Printing Office).

Innes, J. R. (1901) Report on the Census of the Straits Settlements taken on the 1st March 1901 (Singapore: Government Printing Office).

Hare, George Thomson (1902) Federated Malay States, Census of the Population, 1901 (Kuala Lumpur: Goverment Printers). 
Pountney, A. M. (1911) The Census of the Federated Malay States, 1911: Review of the Census Operations and Results Including Tables Exhibiting the Population by Sex, Age, Race, Birthplace, Religion, and Occupation ( London: Darling).

Nathan, J. E. (1922) The Census of British Malaya, 1921 (London: Dunstable and Watford).

Vlieland, C. A. (1932) British Malaya (the Colony of the Straits Settlements and the Malay States under British Protection, Namely the Federated States of Perak, Selangor, Negri Sembilan and Pahang and the States of Johore, Kedah, Kelantan, Trengganu, Perlis and Brunei) a Report on the 1931 Census and on Certain Problems of Vital Statistics (London: Crown Agents for the Colonies).

\section{References}

The Aborigines of the Peninsula. The Straits Times, 21 February 1863, p. 1.

The Aborigines of the Peninsula. The Straits Times, 7 March 1863, p. 1.

Anderson, Benedict (1991) Imagined Communities: Reflections on the Origin and Spread of Nationalism (London: Verso).

Annandale, Nelson, and H.C. Robinson (1903) Fasciculi Malayenses, Anthropological and Zoological Results of an Expedition to Perak and the Siamese Malay States, 1901-1902, Vol. 2, Part 1: Anthropology (London: University Press of Liverpool). 
Appadurai, Arjun (1993) Number in the Colonial Imagination, in Carol A. Breckenridge and Peter van der Veer (eds), Orientalism and the Postcolonial Predicament, pp. 314-340 (Pennsylvania: University of Pennsylvania Press).

Asad, Talal (2002) Ethnographic Representation, Statistics, and Modern Power, in Brian Keith Axel (ed), From the Margins: Historical Anthropology and its Futures, pp. 66-94 (Durham: Duke University Press).

Barclay, Paul D. (2005) Cultural Brokerage and Interethnic Marriage in Colonial Taiwan: Japanese Subalterns and Their Aborigine Wives, 1895-1930. The Journal of Asian Studies 64(2) pp. 323-360.

Benjamin, Geoffrey (2002) On Being Tribal in the Malay World, in Geoffrey Benjamin and Cynthia Chou (eds), Tribal communities in the Malay World: Historical, Cultural and Social Perspectives, pp. 7-76 (Singapore: ISEAS).

Burns, P.L. (1971), Introduction, in R.J. Wilkinson (1971) Papers on Malay Subjects, selected and introduced by P. L. Burns (Kuala Lumpur: Oxford University Press), pp. 1-8.

Cohn, Bernard S. (1987) An Anthropologist among the Historians and Other Essays (Dehli: Oxford University Press). 
Cohn, Bernard S. (1996) Colonialism and its Forms of Knowledge: The British in India (Princeton: Princeton University Press).

Crawfurd, John (1852) A Grammar and Dictionary of the Malay Language with a Preliminary Dissertation (London: Smith Elder).

Crawfurd, John (1856) A Descriptive Dictionary of the Indian Islands and Adjacent Countries (London: Bradbury and Evans).

Dentan, R.K. (1975) If there were no Malays, who would the Semai be? Contributions to Asian Studies 7, pp. 50-64.

Dentan, R.K. (1997) The Persistence of Received Truth: How the Malaysian Ruling Class Constructs Orang Asli, in R.L. Winzeler (ed) Indigenous Peoples and the State: Politics, Land, and Ethnicity in the Malayan Peninsula and Borneo (New Haven: Yale University Southeast Asia Sturies), pp. 98-134.

Dirks, Nicholas B. (1992) Introduction: Colonialism and culture, in Nicholas B. Dirks (ed) Colonialism and Culture (Ann Arbor: The University of Michigan Press), pp. 1-26.

Ferrando, Olivier (2008) Manipulating the Census: Ethnic Minorities in the Nationalizing States of Central Asia. Nationalities Papers: The Journal of Nationalism and Ethnicity 36(3), pp. 489520. 
Fiskesjö, Magnus (1999) On the `Raw' and the `Cooked' Barbarians of Imperial China. Inner Asia 1(2), pp. 139-168.

Fiskesjö, Magnus (2002) The Barbarian Borderland and the Chinese Imagination: Travellers in Wa Country. Inner Asia 4(1), pp. 81-99.

Gomes, Alberto (2009) Ethnicisation of the Orang Asli: A Case Study of the Semai, in Lim Teck Ghee, Alberto Gomes and Azly Rahman (eds) Multiethnic Malaysia: Past, Present and Future (Petaling Jaya: SIRD), pp. 297-322.

Hirschman, Charles (1986) The Making of Race in Colonial Malaya: Political Economy and Racial Ideology. Sociological Forum 1(2), pp. 330-361.

Hirschman, Charles (1987) The Meaning and Measurement of Ethnicity in Malaysia: An Analysis of Census Classifications. The Journal of Asian Studies 46(3), pp. 555-582.

Kahn, Joel (2006) Other Malays: Nationalism and Cosmopolitanism in the Modern Malay World (Singapore: Singapore University Press).

Kalpagam, U. (1999) Temporalities, History and Routines of Rule in Colonial India. Time and Society 8(1), pp. 141-159. 
Kertzer, David I. and Dominique Arel (2001) Censuses, identity formation, and the struggle for political power, in David I. Kertzer and Dominique Arel (eds), Politics of Race, Ethnicity, and Language in National Census (Port Chester, NY: Cambridge University Press), pp. 1-42.

Khalfani, Akil Kokayi and Tukufu Zuberi (2001) Racial classification and the modern census in South Africa, 1911-1996. Race \& Society 4, pp. 161-176.

Lim, David C.L. (2008) Introduction, in David C.L. Lim (ed), Social Sciences in Asia, Volume 19: Overcoming Passion for Race in Malaysia Cultural Studies (Leiden: Brill), pp. 1-12.

Lye, Tuck-Po (2011) The wild and the tame in protected areas management, Peninsular Malaysia, in Michael R. Dove, Percy E. Sajise and Amity A. Doolittle (eds), Complicating conservation in Southeast Asia: Beyond the sacred forest (Durham, NC: Duke University Press) pp. 37-61.

Manickam, Sandra Khor (2011) Taming Race: The Construction of Aborigines in Colonial Malaya, 1783-1937. Unpublished PhD thesis. The Australian National University, Australia.

Manickam, Sandra Khor (2012) Situated thinking: Or how the science of race was socialised in British Malaya. Journal of Pacific History, 2012, ifirst, pp. 1-25.

Marsden, William (1812) A Dictionary of the Malayan Language, in Two Parts, Malayan and English and English and Malayan (London: Cox and Baylis). 
Martin, Rudolf (1905) Die Inlandstämme der Malayischen Halbinsel: wissenschaftliche Ergebnisse einer Reise durch die vereinigten malayischen Staaten (Jena: G. Fischer).

Maxwell, W. E. (1879) The Aboriginal Tribes of Perak. Journal of the Straits Branch of the Royal Asiatic Society 4, pp. 46-50.

Miklouho-Maclay, N. (1875) Ethnological Excursions in the Malay Peninsula-November 1874 to October 1875 (Preliminary Communication). Journal of the Straits Branch of the Royal Asiatic Society 1, pp. 205-221.

Nah, Alice M. (2003) Negotiating indigenous identity in postcolonial Malaysia: beyond being ‘not quite/not Malay’. Social Identities 9(4), pp. 511-534.

Nah, Alice M. (2008) Recognizing indigenous identity in postcolonial Malaysian law: Rights and realities for the Orang Asli (aborigines) of Peninsular Malaysia. Bijdragen tot de Taal-, Land- en Volkenkunde 164 (2/3), pp. 212-237.

Nobles, Melissa (2000) Shades of Citizenship: Race and the Census in Modern Politics (Palo Alto: Stanford University Press).

Peabody, Norbert (2001) Cents, Sense, Census: Human Inventories in Late Precolonial and Early Colonial India. Comparative Studies in Society and History 43, pp. 819-850. 
Pels, Peter (1997) The Anthropology of Colonialism: Culture, History and the Emergence of Western Governmentality. Annual Review of Anthropology 1997, 26, pp. 163-183

Rusaslina Idrus (2011) Malays and Orang Asli: Contesting Indigeneity, in Maznah Mohamad and Syed Muhd Khairudin Aljunied (eds) Melayu: The Politics, Poetics and Paradoxes of Malayness (Singapore: NUS Press), pp. 101-123.

Skeat, W. W. (1902) The Wild Tribes of the Malay Peninsula. Journal of the Anthropological Institute of Great Britain and Ireland 32, pp. 124-141.

Skeat, W. W. and C. O. Blagden (1906). Pagan Races of the Malay Peninsula. Vol. 1 and 2. (London: Macmillan).

Swettenham, F. A. (1948) British Malaya: An Account of the Origin and Progress of British Influence in Malaya (London: George Allen and Unwin, Ltd.).

Teng, Emma (1999) Taiwan as a Living Museum: Tropes of Anachronism in Late-Imperial Chinese Travel Writing. Harvard Journal of Asiatic Studies 59(2), pp. 445-484.

Wilkinson, R. J. (1910) Papers on Malay Subjects: Supplement: The Aboriginal Tribes (Kuala Lumpur: F. M. S. Government Press). 
Wilkinson, R. J. (1920) Papers on Malay Subjects: A History of the Peninsular Malays with Chapters on Perak \& Selangor, $2^{\text {nd }}$ edition (Singapore: Kelly \& Walsh Ltd.).

Wilkinson, R. J. (1971) Papers on Malay Subjects, selected and introduced by P. L. Burns (Kuala Lumpur: Oxford University Press).

Winstedt, Richard Olaf, ed. (1923) Malaya: The Straits Settlements and the Federated and Unfederated Malay States (London: Constable). 